\title{
PEMANFAATAN LIMBAH CAIR TAHU SEBAGAI PUPUK ORGANIK CAIR PADA PERTUMBUHAN DAN HASIL TANAMAN SAWI PUTIH (Brasica pekinensis)
}

\author{
Utilization of Tofu Liquid Waste to Growth and Yield of Chicory (Brasica pekinensi) \\ Elisabet Marian ${ }^{1}$, Sumiyati Tuhuteru*1 \\ ${ }^{1}$ Program Studi Agroteknologi, Sekolah Tinggi Ilmu Pertanian Petra Baliem Wamena, Jl. \\ Sanger, Potikelek, Wamena, Papua 99511 \\ e-mail: *sumiyati.tuhuteru@yahoo.com
}

\begin{abstract}
ABSTRAK
Upaya untuk mencapai produksi yang tinggi dapat melalui berbagai asupan sarana produksi seperti pupuk, hormon untuk pertumbuhan atau pestisida banyak digunakan dalam usaha pertanian. Salah satunya adalah dengan penggunaan pupuk organik. Pupuk organik yang digunakan adalah limbah cair tahu dari industri tahu. Limbah tahu mengandung unsur hara $\mathrm{N}$ 1,24\%, P2O5 5.54 \%, K2O 1,34 \% dan C-Organik 5,803 \% yang merupakan unsur hara essensial. Penelitian ini bertujuan untuk mengetahui pengaruh pemberian limbah cair tahu terhadap pertumbuhan dan hasil tanaman sawi putih (Brassica pekinensis). Penelitian dilaksanakan pada Juni hingga Agustus 2018 dengan susunan rancangan percobaan adalah Rancangan Acak Kelompok Lengkap (RAKL), yang terdiri atas T0: Konsentrasi 0\%; T1: Konsentrasi 10\%; T2: Konsentrasi 20\%; T3: Konsentrasi 30\%; T4: Konsentrasi 40\%. Hasil penelitian yang diperoleh menunjukkan pemberian perlakuan pupuk cair organik limbah cair tahu mampu meningkatkan pertumbuhan dan hasil tanaman sawi putih secara nyata pada semua parameter pengamatan yaitu tinggi tanaman, jumlah daun, dan berat segar tanaman. Konsentrasi terbaik adalah $10 \%$ (T1) dan $20 \%$ (T2) dalam meningkatkan parameter tinggi tanaman dan jumlah daun. Sedangkan, kosentrasi terbaik parameter produksi adalah konsentrasi $30 \%$ (T3), dengan berat produksi $13,57 \mathrm{gr}$.
\end{abstract}

Kata kunci: Limbah Cair Tahu, Pekinensis, Pupuk Organik Cair, Sawi, Tahu.

\section{ABSTRACT}

Efforts to achieve high production can be through various intake of production facilities such as fertilizers, growth hormones or pesticides that are widely used in agriculture. One of them is by using organic fertilizer. The organic fertilizer used is tofu liquid waste from the tofu industry. Tofu waste contains nutrients $N 1.24 \%, P 2 O 55.54 \%, K 2 O 1.34 \%$ and C-Organic $5.803 \%$ which are essential nutrients. This study aims to determine the effect of tofu liquid waste on the growth and yield of chicory (Brassica pekinensis). The study was conducted in June to August 2018 with the composition of the experimental design was carried out using Completly Randomized Block Design (RCBD), which consists of T0: 0\% concentration; T1: 10\% concentration; T2: Concentration of 20\%; T3: 30\% concentration; T4: Concentration of 40\%. The results obtained showed that the application of tofu liquid organic fertilizer fertilizer tofu was able to significantly increase the growth and yield of chicory on all observation parameters, namely plant height, number of leaves, and fresh weight of the plant. The best concentrations are 10\% 
(T1) and 20\% (T2) in increasing parameters of plant height and number of leaves. Meanwhile, the best concentration of production parameters is a concentration of 30\% (T3), with a production weight of $13.57 \mathrm{gr}$.

Keywords: Chicory, Liquid Organic Fertilizer, Pekinensis, Tofu liquid waste, Tofu

\section{PENDAHULUAN}

Pendahuluan: Tanaman sawi putih (Brassica pekinensis L.) termasuk famili Brassicaceae, berasal dari Tiongkok (China) dan Asia Timur. Tanaman ini merupakan komoditas tanaman hortikultura yang banyak digemari oleh masyarakat karena memilki rasa yang paling enak dibanding jenis sawi yang lain dan mudah didapat. Setiap $100 \mathrm{~g}$ bahan segar sawi mengandung 2,3 g protein, 4,0 g karbohidrat, 0,3 g lemak, $220 \mathrm{mg} \mathrm{Ca}, 38 \mathrm{mg} \mathrm{P}, 2,9 \mathrm{mg}$ Fe, $1.940 \mathrm{mg}$ vitamin A, 0,09 mg vitamin B serta $102 \mathrm{mg}$ vitamin C (Haryanto et al., 2007). Sawi putih termasuk sayuran yang memiliki nilai komersial dan prospek yang baik untuk dikembangkan.

Kesadaran masyarakat akan produk pertanian ramah lingkungan semakin meningkat. Permintaan pangan organik meningkat dengan semakin banyaknya masyarakat di dunia yang mengikuti gaya hidup sehat "back to nature". Konsumen menginginkan pangan yang aman, bernutrisi tinggi, dan ramah lingkungan. Beberapa sumber hara yang dapat digunakan dalam sistem pertanian organik adalah bahan organik yang berasal dari pupuk kandang, pupuk hijau, limbah pertanian, pupuk hayati, dan limbah rumah tangga atau perkotaan.

Penggunaan pupuk hayati sebagai penyuplai unsur hara bagi tanaman merupakan salah satu alternatif untuk mensubstitusi penggunaan pupuk anorganik yang berlebihan. Menurut Simanungkalit (2001) aplikasi pupuk hayati dan pupuk kimia terpadu mampu meningkatkan efisiensi penggunaan pupuk $\mathrm{P}$ dengan mengurangi dosis pupuk. Berkurangnya dosis ini akan membantu upaya menekan risiko pencemaran lingkungan dan menghemat sumber daya.

Upaya untuk mencapai produksi yang tinggi dapat melalui berbagai asupan sarana produksi seperti pupuk, hormon untuk pertumbuhan atau pestisida banyak digunakan dalam usaha pertanian. Salah satunya adalah dengan penggunaan pupuk organik. Pupuk organik yang digunakan adalah limbah cair tahu dari industri tahu.

Air limbah tahu merupakan air sisa penggumpalan tahu yang dihasilkan selama proses pembuatan tahu. Pada waktu pengendapan tidak semua mengendap, dengan demikian sisa protein yang tidak tergumpal dan zat-zat lain yang larut dalam air akan terdapat dalam limbah cair tahu yang dihasilkan. Limbah cair tahu merupakan sisa dari proses pencucian, perendaman, penggumpalan, dan pencetakan selama pembuatan tahu. Limbah cair tahu banyak mengandung bahan organik dibandingkan bahanan organik. Kandungan protein limbah cair tahu mencapai 40-60 \%, karbohidrat 25-50\%, dan lemak $10 \%$. Bahan organik berpengaruh terhadap tingginya fosfor, nitrogen, dan sulfur dalam air (Hikmah, 2016). Limbah tahu diketahui mengandung BOD (Biological Oxygen Demand) sebesar 5000-10.000 mg/l dan COD (Chemical Oxygen Demand) $700012.000 \mathrm{mg} / \mathrm{l} \mathrm{serta} \mathrm{tingkat} \mathrm{kemasaman} \mathrm{yang} \mathrm{sangat} \mathrm{rendah,} \mathrm{yaitu} \mathrm{4-5.} \mathrm{Suhu} \mathrm{dari} \mathrm{limbah} \mathrm{tahu}$ dapat mencapai $40-46{ }^{\circ} \mathrm{C}$ dan dapat mempengaruhi kehidupan biologis, kelarutan oksigen, dan

gas lainnya, juga kerapatan air, viskositas, dan tegangan permukaan. Bahan organik yang terkandung dalam limbah tahu berupa karbohidrat sebesar 25-50\%, protein sebanyak 40-60\%, 
lemak sebesar $10 \%$ dan minyak (Sugiharto, 1997). Selain itu, penggunaan limbah cair tahu sebagai pupuk organik merupakan salah satu alternatif.

Limbah cair tahu didapat dari hasil samping pembuatan tahu. Pabrik tahu di Wamena cukup memadai skalanya dan menghasilkan limbah tahu yang dapat dimanfaatkan sebagai pupuk organik untuk budidaya pertanian, termasuk tanaman sawi putih. Jumlah kebutuhan air proses pembuatan tahu dan jumlah limbah cair yang dihasilkan dilaporkan sebesar 43,5 - 45 liter untuk tiap kilogram bahan baku kacang kedelai (Lisnasari, 1995). Limbah tahu mengandung unsur hara N 1,24\%, P2O5 $5.54 \%$, K2O 1,34 \% dan C-Organik 5,803 \% yang merupakan unsur hara essensial yang dibutuhkan tanaman (Asmoro, 2008). Unsur hara $\mathrm{N}$ berpengaruh terhadap pertumbuhan vegetatif tanaman pakcoy seperti penambahan tinggi tanaman dan luas daun. Kandungan hara pada limbah cair tahu yang telah difermentasi dapat langsung diserap oleh tanaman (Amin et al. 2017). Kemudian, Sarwono dkk (2004) menyatakan sifat limbah cair dari pengolahan tahu antara lain sebagai berikut: 1. Limbah cair mengandung zat-zat organik terlarut yang cenderung membusuk jika dibiarkan tergenang sampai beberapa hari di tempat terbuka. 2 . Suhu air tahu rata-rata berkisar antara 40-600 C, suhu ini lebih tinggi dibandingkan suhu ratarata air lingkungan. Pembuangan secara langsung tanpa proses, dapat membahayakan kelestarian lingkungan hidup. 3. Air limbah tahu bersifat asam karena proses penggumpalan sari kedelai membutuhkan bahan penolong yang bersifat asam. Keasaman limbah dapat membunuh mikroba.

Pemanfaatan limbah cair dalam bidang pertanian bukan hal baru lagi. Limbah cair bisa digunakan untuk irigasi tanah pertanian karena limbah mengandung unsur hara $\mathrm{N}, \mathrm{P}, \mathrm{K}$ (Indahwati, 2008). Hindersah (2011) merekomendasikan penggunaan limbah tahu dalam pengomposan dengan tujuan efisiensi pengomposan dan meningkatkan nilai ekonomis limbah tahu. Berdasarkan uraian tersebut, penelitian ini bertujuan untuk mengetahui pengaruh pemberian limbah cair tahu terhadap pertumbuhan dan hasil tanaman sawi putih (Brassica pekinensis).

\section{METODE PENELITIAN}

Metode Penelitian: Bahan yang digunakan adalah polybag, benih sawi putih dan limbah cair tahu dan pupuk kandang sedangkan alat yang digunakan adalah cangkul, gelas kimia, timbangan, sprayer, penggaris, kertas label, dan alat tulis. Penelitian disusun menggunakan metode Rancangan Acak Kelompok (RAK) dengan 1 perlakuan dan 3 kali ulangan. Pemberian limbah cair tahu, yang terdiri dari : T0 : Tanpa pemberian pupuk limbah cair tahu, T1 : Pemberian pupuk limbah cair tahu $10 \%$, T2 : Pemberian pupuk limbah cair tahu $20 \%$, T3 : Pemberian pupuk limbah cair tahu $30 \%$, T4 : Pemberian pupuk limbah cair tahu $40 \%$.

Media tanam untuk penanaman sawi putih berasal dari campuran tanah dan pupuk kandang dimasukkan kedalam polibag dengan perbandingan $2: 1$. Media tanam yang di campurkan dengan pupuk kandang yaitu tanah top soil, keduanya dicampurkan, selanjutnya diisikan kedalam polibag yang berukuran $30 \times 35 \mathrm{~cm}$.

Penanaman sawi puth dilakukan secara langsung di dalam polibag, tanpa melalui proses persemaian. Penanaman dilakukan pada sore hari. Satu polibag di isi tiga benih. Penanaman dilakukan dengan cara ditugal dengan kedalaman 1-2 cm. Kemudian benih dibenamkan. Sehari 
sebelum penanaman tanah harus diairi terlebih dahulu. Sehingga kondisi tanah pada saat penanaman dalam kondisi lembab.

\section{Pembuatan Limbah Cair Tahu}

Limbah cair diperoleh dari salah satu pabrik industri Tahu. Limbah cair tahu yang diambil merupakan hasil perasan tahu yang selanjutnya tidak digunakan. Limbah cair tahu diambil sebanyak kebutuhan yang dibutuhkan, dan merupakan limbah yang berumur $1-2$ hari setelah diperas. Hasil perasan tersebut ditampung kedalam jirigen yang kemudian diukur konsentrasinya berdasarkan perlakuan yang telah ditetapkan, yakni dengan cara sebagai berikut :

- T0: Konsentrasi 0\% (Kontrol), hanya menggunakan air sebanyak $5000 \mathrm{ml}$.

- T1: Konsentrasi 10\%, (400 ml limbah cair tahu + air sebanyak $3600 \mathrm{ml}$ ).

- T2: Konsentrasi 20\%, (800 ml limbah cair tahu + air sebanyak $3200 \mathrm{ml}$ ).

- T3: Konsentrasi 30\%, (1200 ml limbah cair tahu + air sebanyak $2800 \mathrm{ml}$ ).

- T4: Konsentrasi 40\%, (1600 ml limbah cair tahu + air sebanyak $2400 \mathrm{ml})$

Pupuk limbah cair tahu di berikan pada tanaman sawi putih dengan cara disiram pada tanaman sesuai dengan dosis dan perlakuan masing-masing pada saat tanaman berumur 1 dan 3 minggu setelah tanam (MST). Setelah proses penanaman dan pemberian perlakuan dilakukan. Tahapn selanjutnya adalah proses pemeliharaan tanaman yang meliputi:

a. Penyiraman; Penyiraman dilakukan dengan menggunakan gembor pada pagi dan sore hari dan disesuaikan dengan kondisi lingkungan tempat penelitian. Penyiraman dengan selang waktu dua kali sehari, yakni pada pagi dan sore hari. Namun, hanya dilakukan apabila media tumbuh terlihat mulai kering.

b. Penyiangan gulma; Proses penyiangan dilakuan setiap saat, dengan mencabut setiap rumput atau tanaman pengganggu yang tumbuh disekitar area penanaman. Hal ini bertujuan untuk menghindari adanya persaingan dalam menyerap unsur hara yang terkandung dalam tanah dan terkait penerimaan pencahayaan matahari.

Parameter pengamatan dalam penelitian itu terdiri dari parameter pertumbuhan dan parameter hasil. Parameter pertumbuhan terdiri atas perhitungan tinggi tanaman $(\mathrm{cm})$ dan jumlah daun (helai) tanaman sawi putih. Kedua parameter ini diukur pada saat tanaman berumur 2 hingga 7 MST. Sedangkan parameter hasil adalah parameter bobot segar tanaman (gr) yang diukur pada 9 MST atau setelah tanaman dipanen. Data hasil penelitian dianalisis dengan Analisis varians (ANOVA). Selanjutnya untuk mengetahui perlakuan yang berbeda nyata dilanjutkan dengan Uji Beda Nyata Terkecil (BNT) pada taraf $5 \%$.

\section{HASIL DAN PEMBAHASAN}

Hasil pemberian perlakuan pupuk orgnik cair organik dari limbah cair tahu terhadap parameter tinggi tanaman sawi putih, jumlah daun dan bobot segar tanaman yang diamati menunjukkan respon yang bervariasi. Berdasarkan analisis sidik ragam (Tabel 1), hasil penelitian parameter tinggi tanaman pada pengamatan 5 dan 7 MST menunjukkan pengaruh yang tidak berbeda nyata, dibandingkan pada pengamatan 2, 3, 4 dan 6 MST. Sedangkan, pada parameter jumlah daun terlihat berbeda nyata hanya pada pengamatan 5 MST. Pada parameter tinggi tanaman (Tabel 1) perlakuan pupuk organik cair dari limbah cair tahu memiliki tinggi 
tanaman yang lebih baik bila dibandingankan dengan tanaman yang tidak diberi perlakuan pupuk, yakni pada pengamatan 2 MST perlakuan T1 menunjukkan nilai rerata tinggi tanaman tertinggi $(10,33 \mathrm{~cm})$ dan pada pengamatan 6 MST perlakuan terbaik juga ditunjukkan oleh perlakuan T1 dengan nilai rerata tinggi tanaman sebesar 18,33 cm. Sedangkan, pada pengamatan 3 dan 4 MST ditunjukkan oleh perlakuan T2, dimana rerata tinggi tanaman yang ditunjukkan masing-masing sebesar $13,50 \mathrm{~cm}$ dan $15,33 \mathrm{~cm}$ dan berpengaruh nyata terhadap tanaman kontrol (T0). Untuk itu, dapat dikatakan bahwa perlakuan T1 dan T2 merupakan konsentrasi limbah tahu optimal. Hal ini dikarenakan unsur hara yang berasal dari medium tanam maupun dari pemupukan limbah cair tahu konsentrasi 10\% - 20\% telah dapat memenuhi ketersediaan dan serapan hara oleh tanaman dan digunakan untuk pertumbuhan tinggi tanaman. Selain memperbaiki sifat kimia tanah, pemberian limbah cair tahu sebagai pupuk organik juga dapat memperbaiki sifat fisik dan biologi tanah.

Menurut Sutanto (2003), penambahan pupuk organik dapat memperbaiki sifat fisik, kimia dan biologi tanah sehingga lebih subur. Hal ini dikarenakan tanaman dapat memanfaatkan unsur hara di dalam tanah yang meningkat akibat perlakuan limbah cair tahu. Seperti yang dikemukakan oleh Ajeng (2015) bahwa aplikasi limbah cair tahu akan meningkatkan ketersediaan hara yang dibutuhkan tanaman untuk menunjang pertumbuhannya.

Pupuk organik diketahui merupakan pupuk yang terbuat dari bahan-bahan organik seperti kotoran hewan dan tanaman yang telah mengalami perombakan oleh mikroorganisme pengurai. Pupuk organik ini terbuat dari limbah proses pembuatan tahu. Limbah merupakan hasil samping dari proses pembuatan tahu baik berbentuk padat, cair dan gas. Limbah padat dihasilkan dari hasil penyaringan dan limbah cair dihasilkan dari proses perebusan. Sebagian besar dari limbah tahu berbentuk cair. Dalam limbah cair tahu banyak sekali senyawa organik yang terkandung didalamnya seperti karbohidrat, protein dan lemak (Makiyah, 2013), dan unsur hara lainnya. Limbah tahu mengandung unsur hara $\mathrm{N} \mathrm{1,24 \% ,} \mathrm{P2O5} 5.54 \%$, K2O 1,34 \% dan C-Organik $5,803 \%$ yang merupakan unsur hara essensial yang dibutuhkan tanaman (Asmoro, 2008). Unsur hara $\mathrm{N}$ berpengaruh terhadap pertumbuhan vegetatif tanaman sawi putih seperti penambahan tinggi tanaman dan jumlah daun tanaman.

Nitrogen adalah salah satu unsur zat yang sangat dibutuhkan dalam proses pertumbuhan tanaman yaitu sebagai penyususun protein yang merupakan senyawa dengan berat molekul tertinggi yang terdiri atas rantai-rantai asam amino yang terikat dengan ikatan peptida. Nitrogen memegang peranan penting dalam penyusunan klorofil yang menjadikan tanaman berwarna hijau (Samekto, 2008).

Selain unsur hara N, diduga pada limbah cair tahu terdapat kandungan unsur hara $\mathrm{P}$ dan $\mathrm{K}$, yang sangat dibutuhkan tanaman untuk proses fisiologis dan metabolisme hingga dapat meningkatkan laju pertumbuhan tanaman termasuk tinggi tanaman. Selain itu, unsur N berperan dalam pembentukan klorofil, semakin tinggi $\mathrm{N}$ yang diserap oleh tanaman maka klorofil yang dibentuk semakin meningkat. Klorofil berfungsi sebagai pengabsorbsi cahaya matahari dan dapat meningkatkan laju fotosintesis, sehingga fotosintat yang dihasilkan dapat dimanfaatkan untuk meningkatkan pertumbuhan tinggi tanaman. Gardner dkk. (1991) menyatakan unsur hara $\mathrm{N}$ sebagai salah satu unsur hara yang berfungsi sebagai pembentuk klorofil sehingga meningkatkan proses fotosintesis. 
Unsur hara P berperan dalam pembentukan adenosin trifosfat (ATP). ATP adalah energi yang dibutuhkan tanaman dalam setiap aktivitas sel yang meliputi pembesaran sel dan perpanja/ngan sel diantaranya pada batang yang dapat meningkatkan pertumbuhan tinggi tanaman. Hakim dkk. (1986) menyatakan bahwa unsur $\mathrm{P}$ berperan diantaranya dalam pembentukan ATP. Selain N dan P, unsur hara K juga berperan dalam pertambahan tinggi tanaman melalui perannya sebagai aktivator enzim dalam fotosintesis dan fotosintat yang dihasilkan dimanfaatkan untuk meningkatkan tinggi tanaman. Lakitan (2010) menyatakan unsur hara kalium berperan sebagai aktivator dari berbagai enzim esensial dalam reaksi-reaksi fotosintesis dan respirasi serta enzim yang berperan dalam sistesis pati dan protein.

Pemberian pupuk organik pada tanah memberikan pengaruh terhadap biologi tanah yaitu meningkatkan aktivitas mikroorganisme tanah dan keragaman mikroba tanah. Semakin tinggi populasi dalam media tanam menyebabkan proses dekomposisi meningkat sehingga unsur hara dalam tanah menjadi tersedia bagi tanaman. Thabrani (2011) menyatakan unsur hara akan terpenuhi secara maksimal sejalan dengan peningkatan jumlah bahan organik pada tanah yang berperan dalam meningkatkan jumlah mikroorganisme didalam tanah dan berperan dalam proses dokomposisi dan berpengaruh pada suplai hara.

Respon yang ditunjukkan oleh tinggi tanaman, juga diikuti oleh parameter jumlah daun tanaman. Meskipun dari hasil penelitian hanya pada 5 MST yang menunjukkan adanya pengaruh nyata (Tabel 2), dengan jumlah daun terbanyak ditunjukkan oleh perlakuan T1 $(12,67$ helai) dan berbeda nyata dengan tanaman kontrol (T0). Sedangkan, pada pengamatan 2, 4, 3, 6 dan 7 MST menunjukkan pengaruh yang tidak nyata. Konsentrasi $10 \%$ (T1) menunjukkan jumlah daun terbanyak pada tanaman sawi, berbeda nyata dengan konsentrasi $0 \%$. Hal ini karena pemberian limbah cair tahu mampu menyuplai unsur hara makro dalam jumlah yang cukup untuk meningkatkan jumlah daun. Menurut Novizan (2002), unsur hara yang diberikan melalui pemupukan akan memberikan efek fisiologis sehingga pertumbuhan tanaman menjadi lebih baik. Pemberian limbah cair tahu dapat meningkatkan bahan organik dalam tanah dan dapat membantu aktivitas mikroorganisme di dalam tanah. Hal ini dikarenakan limbah cair tahu mengandung C-Organik sebesar 5,803\%, sebagai bahan organik di dalam tanah merupakan sumber makanan, energi dan karbon bagi mikroorganisme. Mikroorganisme berperan dalam memperbaiki struktur tanah sehingga menjadi lebih baik dan unsur hara tersedia terutama $\mathrm{N}$ dan $P$ dapat diserap tanaman dengan baik untuk pertumbuhan tanaman.

Lingga (2003) menyatakan bahan organik mampu memperbaiki struktur tanah dengan bentuk butiran tanah yang lebih besar oleh senyawa perekat yang dihasilkan mikroorganisme yang terdapat pada bahan organik. Butiran - butiran tanah yang lebih besar akan memperbaiki permeabilitas dan agregat tanah sehingga daya serap serta daya ikat tanah akan meningkat. Unsur hara $\mathrm{N}$ merupakan unsur hara yang berperan terhadap pertumbuhan dan perkembangan daun. Unsur $\mathrm{N}$ merupakan bahan dasar yang diperlukan untuk membentuk asam amino yang akan dimanfaatkan untuk proses metabolisme tanaman sehingga akan mempengaruhi pertambahan jumlah daun. Selain itu, Lahuddin (2007) menyatakan unsur hara yang berpengaruh terhadap pertumbuhan dan perkembangan daun adalah unsur $\mathrm{N}$. Unsur $\mathrm{N}$ dimanfaatkan tanaman untuk pembentuk klorofil, asam amino dan protein sehingga mampu membentuk organ-organ pertumbuhan di antaranya pembentukan daun. Jumlah daun akan 
mempengaruhi laju fotosintesis pada tanaman, semakin banyak daun yang terbentuk maka laju fotosintesis meningkat sehingga produksi fotosintat meningkat. Fotosintat tidak hanya digunakan untuk pembentukan daun tetapi juga digunakan untuk pertumbuhan vegetatif seperti tinggi tanaman.

Tinggi tanaman mempengaruhi jumlah daun tanaman sawi putih. Semakin tinggi tanaman maka jumlah daun juga akan meningkat karena daun terletak pada buku - buku batang. Lakitan (2010) menyatakan umur tanaman berpengaruh terhadap pertambahan daun dan stadia perkembangan daun yang akan mempengaruhi laju fotosintesis, semakin banyak jumlah daun maka fotosintesis akan meningkat. Banyaknya jumlah daun juga dipengaruhi oleh pertambahan jumlah sel dan pembesaran sel. Proses ini terjadi akibat pembelahan mitosis pada jaringan bersifat meristematik. Menurut Latarang dan Syakur (2006) bahwa pembentukan jumlah daun sangat ditentukan oleh jumlah dan ukuran sel, juga dipengaruhi oleh unsur hara yang diserap akar untuk dijadikan sebagai bahan makanan. Harjadi (1991), menyatakan pada fase vegetatif hasil fotosintesis secara kompetitif pertumbuhannya akan ditranslokasikan ke akar, batang dan daun. Sejalan dengan Lakitan (1996), yang menyatakan perkembangan dan peningkatan jumlah daun dan ukuran daun (aktivitas jaringan meristematik) dipengaruhi oleh ketersediaan air dan zat hara dari media, sebab air dan zat hara yang terlarut akan diangkut kebagian atas tanaman dan sebagian lagi akan digunakan untuk meningkatkan tekanan turgor sel daun, kemampuan daun dalam berfotosintesis akan meningkat apabila didukung oleh ketersediaan unsur hara.

Nitrogen merupakan unsur hara yang dibutuhkan tanaman untuk pembentukan protein di dalam sel-sel vegetatif tanaman. Pemberian $\mathrm{N}$ akan menyebabkan pertumbuhan vegetatif berlangsung baik dan warna daun menjadi hijau tua (Leiwakabessy, 1998). Hal ini kemudian akan berpengaruh pada jumlah fotosintat yang terbentuk. Ini dapat dilihat pada parameter produksi yang diamati atau dilakukan pada saat proses pemanenan. Proses pemanenan dilakukan apabila daun sudah membuka penuh pada 25-30 HST. Secara statistik, perlakuan limbah cair tahu yang diberikan menunjukkan pengaruh nyata terhadap produksi tanaman (bobot segar tanaman) yang ditunjukkan oleh perlakuan T3 (13,57 gr). Hal ini diduga, kandungan hara N, P dan $\mathrm{K}$ pada limbah cair tahu sangat penting bagi pertumbuhan tanaman. $\mathrm{N}$ berperan dalam pembentuk klorofil. Semakin tinggi kandungan klorofil yang terdapat pada daun maka penyerapan cahaya matahari yang diterima oleh daun semakin tinggi. Dengan demikian fotosistesis akan semakin maksimal yang menghasilkan fotosintat yang digunakan sebagai energi untuk pertumbuhan tanaman. Meskipun sebelumnya jumlah daun pada perlakuan T3 tidak menunjukkan pengaruh nyata terhadap T1. Namun, hal ini berkaitan erat dengan proses dekomposisi hara tanah dan proses suplai hara dalam tubuh tanaman.

Menurut Soepardi (1983), dekomposisi bahan organik tanah akan melepaskan unsur hara yang tersedia bagi tanaman. Unsur hara yang tersedia bagi tanaman merupakan salah satu faktor yang menunjang kegiatan fisiologis tanaman, seperti proses fotosintesis. Semakin banyak proses dekomposisi oleh mikroorganisme dekomposer maka ketersediaan unsur hara dalam media tanam akan meningkat sehingga akan berpengaruh terhadap produksi tanaman. Dwijoseputro (1988) menyatakan bahwa ketersediaan unsur hara dalam keadaan cukup maka proses fotosintesis akan dapat berjalan dengan lancar, sehingga asimilat dapat ditranslokasikan ke seluruh bagian tanaman dan pada akhirnya terjadi peningkatan bobot segar tanaman. 
Bobot segar tanaman dipengaruhi oleh pertambahan tinggi tanaman, jumlah daun dan luas daun. Daun merupakan organ vegetatif tanaman dimana jumlahnya sangat mempengaruhi pertumbuhan tanaman karena daun merupakan organ tempat terjadinya fotosintesis. Terjadinya peningkatan berat segar tanaman berhubungan erat dengan pertambahan jumlah daun yang cenderung lebih banyak. Semakin banyak jumlah daun maka jumlah klorofil juga meningkat. Klorofil berperan dalam proses fotosintesis sehingga fotosintesis akan berjalan dengan lancar dan fotosintat yang dihasilkan juga meningkat.

Hasil fotosintat ditranslokasikan keseluruh jaringan tanaman sehingga berpengaruh terhadap peningkatan berat segar tanaman. Menurut Nyakpa dkk. (1988), terdapatnya klorofil yang cukup pada daun menyebabkan daun memiliki kemampuan untuk menyerap cahaya matahari, sehingga akan meningkatkan proses fotosintesis. Peningkatan laju fotosintesis dipengaruhi oleh pembukaan stomata yang optimal. Hal ini menunjukkan adanya unsur kalium yang mengakibatkan pembukaan stomata lebih optimal. Dimana, pembukaan stomata yang optimal berpengaruh pada proses fotosintesis melalui peningkatan serapan gas $\mathrm{CO}_{2}$. Meningkatnya $\mathrm{CO}_{2}$ yang dapat diserap oleh tanaman akan mengakibatkan meningkatnya laju fotosintesis (Salisbury and Ross, 1992). Peningkatan laju fotosintesis akan mengakibatkan peningkatan bobot tanaman yang akan meningkatkan bobot produksi. (Falasifa, et al., 2014).

Peningkatan bobot segar tanaman juga dipengaruhi oleh kadar air dalam jaringan dimana proses fisiologi yang berlangsung pada tanaman berkaitan erat dengan air dan bahan-bahan yang terlarut dalam air. Prawinata dkk. (1989) menyatakan berat segar tanaman merupakan cerminan dari komposisi unsur hara dan air yang diserap. Lebih $70 \%$ dari berat total tanaman adalah air. Menurut Lakitan (1996) berat segar tanaman tergantung kadar air dalam jaringan dimana proses fisiologi yang berlangsung pada tumbuhan banyak berkaitan dengan air. Peningkatan terhadap parameter bobot segar tanaman dapat dilihat pada Gambar 1.

Tabel 1. Pengaruh pupuk cair organik limbah cair tahu terhadap tinggi tanaman sawi putih $(\mathrm{cm})$

\begin{tabular}{ccccccc}
\hline \multirow{2}{*}{ Perlakuan } & \multicolumn{7}{c}{ Tinggi Tanaman $(\mathbf{c m} /$ MST) } \\
\cline { 2 - 7 } & $\mathbf{2}$ MST & $\mathbf{3 ~ M S T}$ & $\mathbf{4 ~ M S T}$ & $\mathbf{5 ~ M S T}$ & $\mathbf{6}$ MST & $\mathbf{7 ~ M S T}$ \\
\hline T0 & $8,30 \mathrm{~b}$ & $9,20 \mathrm{~b}$ & $11,67 \mathrm{~b}$ & $13,17 \mathrm{a}$ & $15,50 \mathrm{~b}$ & $17,00 \mathrm{a}$ \\
T1 & $10,33 \mathrm{a}$ & $12,33 \mathrm{a}$ & $14,67 \mathrm{a}$ & $16,00 \mathrm{a}$ & $18,33 \mathrm{a}$ & $20,17 \mathrm{a}$ \\
T2 & $9,67 \mathrm{a}$ & $13,50 \mathrm{a}$ & $15,33 \mathrm{a}$ & $16,87 \mathrm{a}$ & $18,17 \mathrm{a}$ & $20,00 \mathrm{a}$ \\
T3 & $9,13 \mathrm{ab}$ & $12,67 \mathrm{a}$ & $15,33 \mathrm{a}$ & $16,37 \mathrm{a}$ & $18,00 \mathrm{a}$ & $20,00 \mathrm{a}$ \\
T4 & $9,00 \mathrm{ab}$ & $12,00 \mathrm{a}$ & $15,00 \mathrm{a}$ & $16,67 \mathrm{a}$ & $17,67 \mathrm{a}$ & $19,33 \mathrm{a}$ \\
\hline Rata-rata & $\mathbf{9 , 2 3}$ & $\mathbf{1 1 , 9 4}$ & $\mathbf{1 4 , 4 0}$ & $\mathbf{1 5 , 8 1}$ & $\mathbf{1 7 , 5 3}$ & $\mathbf{1 9 , 3 0}$ \\
\hline Koefisien & $\mathbf{8 , 4 0}$ & $\mathbf{9 , 3 7}$ & $\mathbf{5 , 7 4}$ & - & $\mathbf{5 , 2 5}$ & $\mathbf{4 , 0 7}$ \\
\hline
\end{tabular}

Keterangan : Nilai yang diikuti dengan huruf yang sama pada kolom yang sama tidak berbeda nyata dengan uji lanjut BNT pada $\alpha=5 \%$; T0 (tanpa pemberian pupuk limbah cair tahu), T1 (pemberian pupuk limbah cair tahu $10 \%$ ), T2 (pemberian pupuk limbah cair tahu $20 \%$ ), T3 (pemberian pupuk limbah cair tahu $30 \%$ ), T4 (pemberian pupuk limbah cair tahu $40 \%$ ). 
Tabel 2. Pengaruh pupuk cair organik limbah cair tahu terhadap jumlah daun sawi putih (helai)

\begin{tabular}{ccccccc}
\hline \multirow{2}{*}{ Perlakuan } & \multicolumn{7}{c}{ Jumlah Daun (Helai/MST) } \\
\cline { 2 - 7 } & 2 MST & 3 MST & 4 MST & 5 MST & 6 MST & 7 MST \\
\hline T0 & $5,33 \mathrm{a}$ & $6,67 \mathrm{a}$ & $9,00 \mathrm{a}$ & $10,33 \mathrm{~b}$ & $11,33 \mathrm{a}$ & $12,67 \mathrm{a}$ \\
T1 & $5,67 \mathrm{a}$ & $7,67 \mathrm{a}$ & $12,33 \mathrm{a}$ & $12,67 \mathrm{a}$ & $13,33 \mathrm{a}$ & $13,33 \mathrm{a}$ \\
T2 & $5,33 \mathrm{a}$ & $7,33 \mathrm{a}$ & $10,00 \mathrm{a}$ & $10,67 \mathrm{ab}$ & $12,67 \mathrm{a}$ & $13,00 \mathrm{a}$ \\
T3 & $5,00 \mathrm{a}$ & $7,00 \mathrm{a}$ & $9,67 \mathrm{a}$ & $11,00 \mathrm{ab}$ & $12,00 \mathrm{a}$ & $12,00 \mathrm{a}$ \\
T4 & $4,67 \mathrm{a}$ & $7,33 \mathrm{a}$ & $9,33 \mathrm{a}$ & $10,33 \mathrm{~b}$ & $11,67 \mathrm{a}$ & $11,67 \mathrm{a}$ \\
\hline Rata-rata & $\mathbf{5 , 2 0}$ & $\mathbf{7 , 2 0}$ & $\mathbf{1 0 , 0 7}$ & $\mathbf{1 1 , 0 0}$ & $\mathbf{1 2 , 2 0}$ & $\mathbf{1 2 , 5 3}$ \\
\hline Koefisien keragaman & - & - & - & $\mathbf{4 , 9 3}$ & - & - \\
$(\mathbf{\%})$ & - & - & - &
\end{tabular}

Keterangan : Nilai yang diikuti dengan huruf yang sama pada kolom yang sama tidak berbeda nyata dengan uji lanjut BNT pada $\alpha=5 \%$; T0 (tanpa pemberian pupuk limbah cair tahu), T1 (pemberian pupuk limbah cair tahu $10 \%$ ), T2 (pemberian pupuk limbah cair tahu $20 \%$ ), T3 (pemberian pupuk limbah cair tahu $30 \%$ ), T4 (pemberian pupuk limbah cair tahu $40 \%$ ).

Tabel 3. Pengaruh pupuk cair organik limbah cair tahu terhadap berat segar (gr)

\begin{tabular}{cc}
\hline Perlakuan & Berat Segar (gram) \\
\hline T0 & $11,30 \mathrm{~b}$ \\
T1 & $11,67 \mathrm{~b}$ \\
T2 & $12,03 \mathrm{ab}$ \\
T3 & $13,57 \mathrm{a}$ \\
T4 & $12,37 \mathrm{ab}$ \\
\hline
\end{tabular}

\section{Rata-rata}

12,19

\section{Koefisien keragaman (\%)}

Keterangan : Nilai yang diikuti dengan huruf yang sama pada kolom yang sama tidak berbeda nyata dengan uji lanjut BNT pada $\alpha=5 \%$; T0 (tanpa pemberian pupuk limbah cair tahu), T1 (pemberian pupuk limbah cair tahu $10 \%$ ), T2 (pemberian pupuk limbah cair tahu $20 \%$ ), T3 (pemberian pupuk limbah cair tahu $30 \%$ ), T4 (pemberian pupuk limbah cair tahu $40 \%$ ).

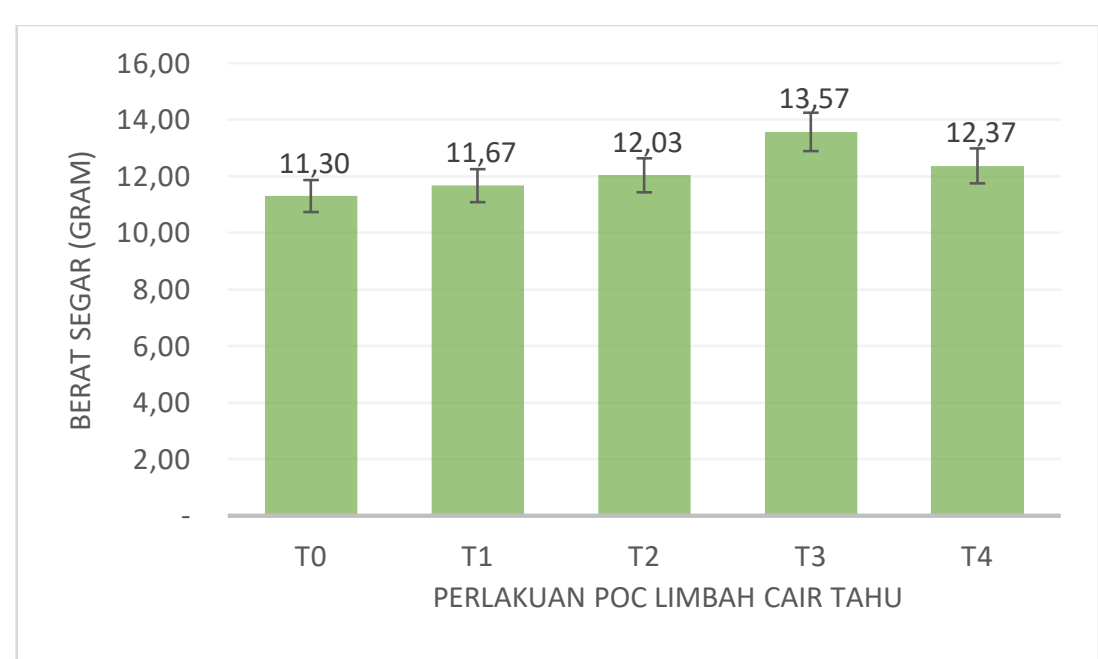

Gambar 1. Pengaruh Pemberian Pupuk Organik Cair Limbah Tahu terhadap Bobot Segar Tanaman Sawi Putih 


\section{KESIMPULAN}

Hasil penelitian yang diperoleh menunjukkan pemberian perlakuan pupuk cair organik limbah cair tahu mampu meningkatkan pertumbuhan dan hasil tanaman sawi putih secara nyata pada semua parameter pengamatan yaitu tinggi tanaman, jumlah daun, dan bobot segar tanaman. Konsentrasi terbaik adalah $10 \%$ (T1) dan $20 \%$ (T2) dalam meningkatkan parameter tinggi tanaman dan jumlah daun. Sedangkan, kosentrasi terbaik parameter produksi adalah konsentrasi $30 \%$ (T3), dengan rerata bobot segar tanaman sebesar 13,57 gr.

\section{DAFTAR PUSTAKA}

Ajeng F. S. 2015. Pemanfaatan Limbah Cair Tahu sebagai Bahan Amelioran Tanah dan Pengaruhnya terhadap Pertumbuhan dan Produksi Tanaman Caisin (Brassica juncea L.). Skripsi. Departemen Ilmu Tanah dan Sumberdaya Lahan Fakultas Pertanian. IPB. Bogor.

Amin Al Ahmad, Yulia En A. Dan Nurbaiti. 2017. Pemanfaatan Limbah Cair Tahu untuk Pertumbuhan dan Produksi Tanaman Pakcoy (Brassica rapa L.). JOM FAPERTA, 4 (2).

Asmoro, Y. 2008. Pemanfaatan limbah tahu untuk peningkatan hasil tanaman petsai (Brassica chinensis). Jurnal Bioteknologi. vol 5 (2): 51 - 55. Program Biosains Pasca Sarjana Universitas Sebelas Maret. Surakarta..

Dwijosaputro, D. 1988. DasarDasar Fisiologi Tanaman. Gramedia. Jakarta

Falasifa A., Slameto dan K. Hariyono. 2014. Effect of seaweed extract Ascophyllum nodosum in powder and liquid form on growth of red leaf lettuce (Lactuca sativa var. crispa). Berkala Ilmiah Pertanian 1:62-64

Gardner, F.P., R.B. Pearce, dan R.L. Mitchell. 1991. Fisiologi Tanaman Budidaya (Terjemahan oleh Herawati Susilo). UI Press. Jakarta.

Hakim, N, M.Y. Nyakpa, A.M. Lubis, S.G. Nugroho, M.R. Saul, M.A. Diha, H.M. Bailey. 1986. Dasar-Dasar Ilmu Tanah. Universitas Lampung.

Harjadi, S.S. 1991. Pengantar Agronomi. Gramedia. Jakarta.

Haryanto W., T. Suhartini dan E. Rahayu. 2007. Teknik Penanaman Sawi dan Selada seca Hidroponik. Jakarta: Penebar Swadaya.

Hikmah N. 2016. Pengaruh Pemberian Limbah Tahu Terhadap Pertumbuhan dan Hasil Tanaman.

Hindersah R. 2011. Pemanfaatan Limbah Tahu dalam Pengomposan Sampah Rumah tangga untuk Meningkatkan Kualitas Mikrobiologi Kompos. Jurnal Agrinimal 1 (2)..

Indahwati. 2008. Pengaruh Pemberian Limbah Cair Tahu terhadap Pertumbuhan Vegetatif Cabai Merah (Capsicum annuum. L) Secara Hidroponik dengan Metode Kultur Serabut Kelapa. Skripsi . Malang: Program Studi Pendidikan Biologi Jurusan Pendidikan Matematika Dan Ilmu Pengetahuan Alam Fakultas Keguruan dan Ilmu Pendidikan Universitas Muhammadiyah.

Lahuddin, M., 2007. Aspek Unsur Mikro Dalam Kesuburan Tanah. USU Press. Medan.

Lakitan, B. 1996. Fisiologi Pertumbuhan dan Perkembangan Tanaman. Raja Grafindo Persada. Jakarta.

Lakitan 2010. Dasar - Dasar Fisiologi Tumbuhan. Rajawali Pers. Jakarta. 
Latarang, B. dan A. Syakur. 2006. Pertumbuhan dan hasil bawang merah (Allium ascalonicum L.) pada berbagai dosis pupuk kandang. J.Agroland. vol. 13 (3): 265-269.

Leiwakabessy, F. M. 1998. Kesuburan Tanah. Bogor: Jurusan Tanah Fakultas Pertanian, Institut Pertanian Bogor.

Lingga, P. 2003. Petunjuk Penggunaan Pupuk. Penebar Swadaya. Jakarta.

Lisnasari, S. F. 1995. Pemanfaatan gulma air (aquatic weed) sebagai upaya pengelolahan limbah cair industri pembuatan tahu. Tesis. Universitas Sumatra Utara. Medan.

Makiyah Mujiatul. 2013. Analisis Kadar N, P dan K pada Pupuk Cair Limbah Tahu dengan Penambahan Tanaman Matahari Meksiko (Thitonia diversivolia). Skripsi. Jurusan Kimia, Fakultas Matematika dan Ilmu Pengetahuan Alam. Universitas Negeri Semarang.

Novizan. 2002. Petunjuk Pemupukan Yang Efektif. Agromedia Pustaka. Jakarta.

Nyakpa, M. Y, A.M. Lubis, M. A. Pulung, A.G. Amroh, A. Munawar, G. B. Hong dan N. Hakim. 1988. Kesuburan Tanah. Universitas Lampung. Lampung.

Prawinata, W., S. Harran dan P. Tjandronegoro. 1989. Dasar - dasar Fisiologi Tumbuhan II. Fakultas Pertanian IPB. Bogor.

Salisbury FB, CW Ross. 1992. Plant Physiology. Belmont - California: Wadsworth Publishing Comp.

Samekto R. 2008. Pemupukan. Yogyakarta: PT. Citra Aji Parama.

Sarwono 2004. Sifat Limbah Tahu. Jakarta

Simanungkalit, R.D.M. 2001. Aplikasi pupuk hayati dan pupuk kimia : suatu pendekatan terpadu. Skripsi. Malang: Program Studi Pendidikan Biologi Jurusan Pendidikan Matematika Dan Ilmu Pengetahuan Alam.

Soepardi, G. 1983. Sifat dan Ciri Tanah. Bogor: Jurusan Tanah, Fakultas Pertanian, Institut Pertanian Bogor.

Sugiharto. 1997. Dasar-dasar Pengolahan Air Limbah. Jakarta: Universitas Indonesia (UI) Press.

Sutanto, R. 2003. Penerapan Pertanian Organik Pemasyarakatan Dan Pengembangan.Kanisius. Yogyakarta.

Thabrani A. 2011. Pemanfaatan Kompos Ampas Tahu Untuk Pertumbuhan Bibit Kelapa Sawit (Elais guinensis Jacq.). Skripsi Fakultas Pertanian, Universitas Riau. (Tidak Dipublikasikan). 